\title{
The Effectiveness of The Tax Regulation Socialization Strategies on Tax Payers' Comprehension and Compliance In Implementing Their Tax Obligations
}

\author{
Hetti Herawati ${ }^{1}$, Roni Tabroni ${ }^{2}$, Senny Lusiana ${ }^{3}$ \\ Fakultas Ekonomi, Universitas Sangga Buana, Bandung, Indonesia ${ }^{1}$ \\ Fakultas Ekonomi, Universitas Sangga Buana, Bandung, Indonesia ${ }^{2}$ \\ Fakultas Ekonomi, Universitas Sangga Buana, Bandung, Indonesia ${ }^{3}$
}

\begin{abstract}
In order to increase state' earning from tax, government should be active in making society awareness on their obedience to pay tax. This study was based on the importance of tax socialization by the tax office to tax payers through different kinds of media. Socialization has been carried out not only by face to face method, but also by mass media appropriate to the recent situation. The goal of this study was to know the socialization strategies done by the Tax Office for the tax payers both through mass media and directly done by the Representative Accountants. Besides, this study also was to evaluate the effectiveness of these strategies on tax-payers' comprehension and their obedience.. The output of this study was the formalization the appropriate socialization standards for the tax office in order to increase the tax-payers' awareness and as a result the tax revenue will increase automatically. First stage, this study observed the Tax Office policies especially on the aspect of tax regulation socialization strategies. Further study on the aspect of media itself as the tool for socialization. Finally, this study would have the conclusion about the relationship between socialization methods and the awareness and the obedience of tax payers in tax payment. This study used descriptive associative methods. The first analysis stage was to test the basic assumption i.e. normality test, and then for the hypothesis testing used Path Analysis. This study concluded that there was the positive correlation between socialization strategy on tax regulation and tax payers' comprehension and the awareness and the obedience of tax payers.
\end{abstract}

Keywords : tax office; representative accountants; tax payers; socialization and obedience.

Article history. Received Agustus, 2018. Revised Oktober, 2018. Accepted December, 2018

Corresponding author. E-mail address: ${ }^{1}$ herawati.hetti@yahoo.co.id

How to cite article. Herawati, H., Tabroni, R., \& Lusiana, S. (2018). The Effectiveness of The Tax Regulation Socialization Strategies o n Tax Payers ' Comprehension and Compliance In Implementing Their Tax Obligations. The International Journal of Business Review (The Jobs Review), 1(2), 131-140. https://doi.org/https://doi.org/10.17509/tjr.v1i2.12980

\section{INTRODUCTION}

The 2017 Indonesian State Budget as the third State Budget for the Kabinet Kerja Government in realizing the Nawacita commitment. Since 2015, government had been focused on giving first priority on infrastructure development, which had been followed by decreasing its poverty level and their inter regional income gaps by keeping the appropriate and sustainable fiscal management.(Sri Mulyani - Pajak Bertutur).

As the budgeter function, tax is still the largest contributor for the Indonesian State Budget on the average of 77.6 percent. The ratio between tax revenue and gross domestic products is targeted by 10.9 percent. Income tax and Added Value Tax are the largest income from the tax i.e. 55.6 percent for income tax and 33 percent for added value tax. Considering income tax as the largest contributor for tax revenue, income tax should be managed optimally.

Until now the tax payers' disobedience had been perceived as the major factor caused the disachievement tax revenue targets. The ratio of the tax payers' obedience between 2013 and 2016 on the average of 59.5 percent, but in 2016 had been increased from 60 to 70 percent especially after 
HETTI HERAWATI, RONI TABRONI, \& SENNY LUSIANA/ The Effectiveness of The Tax Regulation Socialization Strategies on Tax Payers ' Comprehension and Compliance In Implementing Their Tax...

Tax Amnesty Policy implementation. The tax payers obedience level was dominated by the personal tax payers ( Oji Saeroji, 01 March 2017).

The obedience of Bandung City people in paying taxes was still low about 48 percent of all obligated tax payers or about 75,000 peoples, from these, it was only 600,000 tax payers who filled out the SPT( Yearly Announcement Forms) and from these, it was only 60 percent or 360,000 peoples who really paid taxes and the rest or 40 percent were still in debt tax payment. 11

Fiscus as the institution who in charge for this problem ought to know the factors that caused the low of peoples' awareness of their obligation in paying taxes. Was there because of low socialization process from the fiscus side, or was there because of less effective and unapropriate socialization process and it made peoples' less comprehension on application process of tax obligation itself.

In order to achieve the government goals in otimization tax revenue it was necessary to have the effective communication between fiscus/government and tax payers through determining the proper strategy. Communication skills was needed in management because communication is the idea transferring activity from one side to others in keeping same perception about those idea.

The success of communication is indicated by the existence of tax payers' awareness and properly implemented for their rights and obligation on tax payment especially in the process of calculating, predicting, paying and reporting the tax debt payment.

The proper communication strategy is the dominant determinants for the success of tax socialization process for the tax payers. Considering that communication as the social interaction process by giving comprehension to other sides, it should be needed the proper communication planning based on the strategy consist of composition, articulation, rational, tactic, time, fund and evaluation.

Account Representative as a part of tax environments is in charge of giving consultation to the tax payers, and giving direct communication to them, in giving comprehension about tax regulation application. The same comprehension among different Account Representatives about tax regulation is a major important point when they give consultation to the tax payers. If not the case, it will make the ambiguity of the tax payers and as the consequence they will hardly to pay the tax. For this reason, it should needed the equally scientific comprehension, intellectuality, and professionalism among different Account Representatives.

The existence of tax regulation in one side and low level obedience of tax payers on the other side is hypothesized because of the tax regulation has not yet socialization properly. For this reason, this study try to describe the tax regulation socialization implemented by Tax Office in West Java in connection with tax payers' comprehension and their obedience on tax.

As a budget function, tax holds a very important role in running the wheels of Government, and 77.6 percent revenue of this country comes from taxes. Given the important role of such tax matters in running the State, then the management of the tax should be laid out in such a way that the goal can be achieved.

The tax collection system as a self assessment system, is a system of tax collection which gives full trust to the taxpayers to compute, reckon, deposit and report the magnitude of its own debttax. This system demands a harmonious cooperation between the Government as lawmakers with the public (taxpayers), as implementing legislation, so that the goals can be achieved.

Harmonization of communication the two parties is not easy to be implemented, hence the need for planning and the appropriate communication strategy so that the public could apply the statutory rules are appropriate expectations. ${ }_{[5]}$ The large number of rules and punishment given to the taxpayer requires that taxpayers understand the contents of the legislation and are able to apply them. If the taxpayer has not been able to apply the rules to the maximum, then punishment awaits, while socializing and communication from the fiskus party is still questionable effective. 6 George Herbert Mead ${ }^{[7]}$ says: "Socialization is the process by which human beings learn the way, the value and adjust actions by society and culture. With socialization, how human beings improve their personal growth to fit the circumstances, values, norms and culture of the certain society.

Socialization which will be rolled out to the community must reach the target and can be understood by the community, in particular the tax payers. ${ }^{[8]}$ Socializing is done to provide insight 
to taxpayers. ${ }^{[9]}$ To achieve the socialization in the process of communicating the laws of taxation invitation to the community, must be supported by an appropriate communication strategy, as said by Laswell:[10] "The four elements of the planning of the communication strategy to be met, including:

- The Goal, is the future condition will be achieved.

- Action, is the multistage activities carried out to achieve the goal.

- Resources, is all things needed in pursuing the action.

- Implementation,is the way and direction the implementation of activities.

Laswell[111 said, five elements contained in the communication are:

- Communicators : people who deliver the message

- A message : an idea or information delivered

- Media : acommunication tool

- Communican : audience, those who receive the message

- Response : from communican for the messages are received

Given the importance of the matter, then the strategy is a commitment in the unity and determination of the point of view of a number of managing authorities and planners, to achieve the goals that have been set previously. Thereby, the strategy includes a series of stages of human activities in achieving the objectives, using the various elements of the potential, consider the situation and conditions with high accuracy. $\frac{[12]}{}$

The process to reach an agreement (Sharing of meaning), usually takes place gradually. Therefore, the earlier we need to pay attention to the 5 (five) target staple in the communication process, namely:

- Make the listener, to listen to what we say (or see what We show it to them)

- Make the listener, understanding what they hear or see

- Make the listener, agreeing what they have heard (or o not approve what we say, but with the understanding that correctly)

- Make the listener, take appropriate action with the objective and purpose they receive

- Obtain feedback from listeners

In addition, there are still other important factors in the communication process, namely: Interference (noise) i.e. external factors (media/communication channels) or internal (psychological) that can interfere or hinder the smooth the communication process.

A successful socialization process can be seen from the increasing number of taxpayers who carry out the obligation of taxation, this happens based on understanding from taxpayers over the socialization that has rolled out. Understanding instead of mere thinking activities, but rather the transfer of layout in the stands at the world situation or others. Relive the situation encountered in other personal erlabnis (sources of knowledge about the life, activities do experience the mind), the fully hearted comprehension. Understanding is an activity of thinking silently, finds itself in others. $[14]$

Narwoko and Bagong[15] declared that understanding can be distinguished into three categories, namely: first, the lowest level is the understanding of translation, ranging from translating in the actual sense, interpret and apply the principles. The second is an understanding of interpretation, namely connecting parts with the lowest known next or connecting some parts of the graph with the Genesis, a principal with distinguishing which is not principal. And third, is the level of the definition of extrapolation.Having an understanding of the level of extrapolation means a person is able to see behind the writing, can make estimation, prediction based on understanding and condition that is explained in the ideas or symbols, as well as the ability to make conclusions linked to the implications and consequences. [16]

Understanding can be divided into three, namely: first, translating (translation), the notion of translating here not only diverting (translation), the meaning of one language into another 
HETTI HERAWATI, RONI TABRONI, \& SENNY LUSIANA/ The Effectiveness of The Tax Regulation Socialization Strategies on Tax Payers' Comprehension and Compliance In Implementing Their Tax...

language, it can also abstract from conception become a model, i.e. the symbolic models to facilitate people study. ${ }^{[17]}$ The redirection concept formulated with words - words into pictures of graphs can be included in the category of translate. Second, the interpretation, this ability to translate is wider than the ability to know and understand the main ideas of a communication. Third,extrapolation, another bit of translating and interpreting, but higher nature. He demanded a higher intellectual capabilities.

While the tax compliance is the taxpayers have a willingness to fulfill obligations of his taxes. Fulfillment of obligations must comply with the applied tax regulation without the need to have a thorough investigation, examination (obtrusive investigation), warnings, threats, and the application of the law administrative sanctions. Taxpayer compliance meet the obligations of taxes will increase the revenue of the State and in turn will increase the magnitude of the tax ratio. [19]

Erwin Harinurdin $\frac{[20]}{}$ makes it clear that taxpayer compliance includes compliance records or logs the transaction compliance efforts, reported business activities in compliance regulations, and compliance against all other taxation rules. Among the three types of such compliance, the most easily observed are the compliance report on business activity, because the entire taxpayer shall be obliged to deliver its business activity report each month and/or every year in the form of conveying Letter Of Notification (SPT). The Directorate General of Tax through through its employees puts taxpayers report as the main entrance to evaluate taxpayer compliance. Knowledge, experience, and insight into an employee's tax would be very influential in the ' reading ' the report, thus obtained a good overview with regard to compliance by tax payers. [21] Thus fosters compliance with mandatory should be the main agenda of the Directorate General of Taxes. ${ }^{[22]}$

\section{METHOD}

According to Sugiyono ${ }^{[2]}$ research method a scientific way to get certain data, goals and benefits . The scientific way mean the activities that having scientific characteristics i.e. rationality, empirical and systematics. The research method used in this study were descriptive and associative methods. Descriptive methods means describing the value of variables both as one or more variables. or more variables. Whereas the associative method means analyzing the relationship or causal effect phenomenon between two or more variables.

\section{RESULT \& DISCUSSION}

To find out how the response of taxpayers against the socialization through mass media, the discussion of these data results pulled the answers of respondents for the variable X 1 which showed the results of that score for socializing with mass media, the value of 3776 from the ideal score i.e. 6000 with the score on the average value at 3.15. When viewed from " Scoring Category Classification for descriptive statistics ", this score was categorized " enough ".

This showed that socialization rolled out through mass media included: Print Media, electronic media, online media and outdoor media, just got a positive response from the the tax payers community . When viewed from each media, the description as follows:

\section{Socialization through Printed Media}

The taxpayer's response to the socialization initiated by the Directorate General of Taxes through print media shows the score of 3.13 with the category of "good enough", it indicates that the socialization in print media (liflet), got positive response, because the display is quite interesting and the language which is quite easy to understand, so as to guide taxpayers in performing tax obligations that are procedural and normative, such as e-Register procedures, e-Filling, e-Invoice, and e-Billing, PP-46, and others. Existing Information quite relevant to the needs of taxpayers in implementing tax rights and obligations.

\section{Socialization through Electronic Media}


Then, a mandatory response against the tax socialization rolled out through electronic media, it was known that the response of the respondents got a score of 3.19 or "good enough" This indicated that the socialization that rolled out in the form of impressions on radio and television, got quite a positive response because of the look of the picture and sound information non pictures (Audio) repeatedly, causing the community particularly the taxpayer can be given that information quite well. In addition, electronics media got the quite positive response from society over the information provided, as it was quite capable of motivating and urging information where should deposit and reporting taxes, as well as providing information on tax payment deadline. The information was quite helpful in carrying out the obligations of tax payers community.

\section{Socialization through Online Media}

The response of respondents toward socialization through online media, got a score of 3.16 or "good enough". Socialization that rolled out in the form of online media poured in active forms of communication in online the form of tax learning, tax chatting and tax "kring" the ways that were very positive and quite helpful for the tax payers who want to carry out the tax obligation because they were quite attractive and informative, but in practice were still experiencing constraints or less comprehension to carry it out.This media was quite helpful for tax payers although was still felt not optimal because the waiting time were sometimes too long but the answers were too short, especially for taxpayers who were facing the problem of taxation, so the answer is no longer needed and liabilities already carried out.

\section{Socialization through Outdoor Media}

The response of taxpayers against the socialization that rolled out the taxpayer through the outdoor media, was amounted to 3.11 or "good enough". Socialization outdoors such as: banners, ," baligo", and " megatron" who rolled out got a pretty positive response from the public, because the normative information presented was quite clear, quite easy to grasp with a pretty interesting look, as well as the information presented was fairly relevant to their needs. The media has been giving enough information so that means helping taxpayers to know or remember what the rights and obligations.

\section{Socialization through Face-to-face Media}

The response of taxpayers toward the socialization through face-to-face media, in a discussion of these data results drawn from the answers of respondents for the variable $\mathrm{X} 2$ showed the score value of 6493 from 8500 of the ideal score and the score average value at 3.82. Viewed from the table on the " value category classification" for descriptive statistics this score categorized as " good ".This showed that the tax -socialization rolled out through face-to-face media which include: consulting and supervision services performed by an Account Representative (AR), and in house training got a positive response from the community especially taxpayers. Here's the blurb for each face-to-face media:

\section{Socialization through AR Direct Consultation}

Dissemination of information and consulting services performed by AR or known has duty WASKON (Supervision and Consultation), service is very important and strategic. It is said so because the AR is the part that is directly related to the problems of the taxpayer, where the taxpayer can instantly get solutions to problems faced. For that attitude, performance, and competence AR is indispensable in dealing with taxpayers. The answers of respondents over a given questionnaire, indicating the consulting services provided by AR showed score of 3.75 or be on the category "good." This showed that in general, the attitude, performance and competency of the AR is already good, although an assessment of the respondents ' answers to the satisfaction of them was often confusing taxpayers or taxpayer less satisfying.

\section{Socialization by AR through In House Traning}


HETTI HERAWATI, RONI TABRONI, \& SENNY LUSIANA/ The Effectiveness of The Tax Regulation

Socialization Strategies on Tax Payers' Comprehension and Compliance In Implementing Their Tax...

Socialization of information is done by AR through in House Training got a positive response from the taxpayer, with a score value of 3.90 or were on the "good" category. In House Training is one of the socialization that assessed right by taxpayers, because the material is presented in addition to the up date is also urgently needed, and the exposure is delivered, clear and interesting, so as to make the taxpayer prefer In House Training than consulting directly with AR.

\section{Taxpayers' Comprehension about Tax Regulations}

Making an understanding of taxpayers about tax regulations is very important, because by an adequate understanding of expected tax payers can exercise the right and the obligation to calculate, reckon, deposit and report tax indebted. Based on data it was found that the score for the understanding of taxpayers is 3864 from the standard of 5000 and the average score of 3.86 was in the category of "good".This showed that the socialization of tax regulation that rolled out with various media above can be well understood by the tax payers. To find out how the level of understanding of taxpayers over socialization of the regulations, can be viewed on the following exposure.

\section{The Level of Taxpayers' Comprehension about Tax Regulation}

To know the response of taxpayers against the socialization that rolled out taxpayers through AR with direct consultation, can be found the answers of the respondents with regard to the understanding of tax obligations in carrying out the actual score has 2314 from the ideal score 3000 and the average value of 3.86. It means that the score was on the criteria of "good".The answers of respondents stated will be over the obligation to register and have an NPWP, calculating, deposit and reporting real data with the SPT has been done well, while respondent having understood about their obligations to cut and collect taxes.

\section{The Level of Taxpayers' Comprension about Tax Obligation.}

To know the response of taxpayers against the socialization that rolled out taxpayers through AR with direct consultation, can be found the answers of the respondents associated with knowledge in the exercise of their rights as taxpayers has 1550 while the score of ideal was 2000 and average value of 3.88. This means that the score was on the criteria of "good".Answers of respondents stating the existence of a good understanding over his rights as a taxpayer that include: the right to perform compensation or restitution if the excess pay taxes, the right to ask for an explanation with regard to the tax inspection activities, knowing the procedures in filing an objection and the right to appeal.

\section{Taxpayer compliance on Tax Regulations}

Taxpayer compliance in carrying out tax regulation is very expected by the Government, because the taxpayer compliance can increase the revenue of the State. To find out the level of taxpayer compliance in implementing legislation, known score values for compliance are in the range of 3892 from the ideal score i.e. 5000, with average value of 3.89. This figure showed that in general, the level of taxpayer compliance was on the criteria of "good". To find out the level of compliance of the respondents in the process of self assessment system, can be found in the description as follows:

\section{Taxpayer Compliance in Registration}

To find out the level of compliance of taxpayers in registration, in the exercise of one of the tax liability, it can be noted that the actual score has 826 from the ideal score of 1000 and the average value of acquired for 4.13. The value present on the criteria of "good". This showed that the compliance of taxpayers to register at the local and the KPP from all respondents who selected answer already signed up and having NPWP, although there was still some respondents who din't have 
NPWP because his income was still under PTKP or the presence of a new entrepreneur who have yet to understand the tax issues.

\section{Taxpayer Compliance in Reporting SPT}

To find out the level of taxpayer compliance in reporting, such as tax obligations, one can note that the actual score 1208 from the ideal score of 1500 and average values obtained of 4.03. The value was on the criteria of "good". This showed that the compliance of taxpayers to report local KPP in the SPT was implemented as well: fill with complete SPT, true and clear, as well as deliver timely appropriate SPT Statute Law.

\section{Taxpayer compliance in Calculating and Reporting SPT}

To find out the level of compliance by taxpayers in calculating and reporting SPT, as one obligation of taxation, it was known that the actual score was 1162 from the ideal score of 1500 and the average value of 3.87 and was categorized "good". The taxpayers are already obedient in carrying out the taxation duty starting from the process of tax calculations which was done correctly, both in terms of tariff, and based on taxation in accordance with the applicable provisions. In addition, to it taxpayers already depositing taxes to the bank in accordance with the Ordinances of the perception of the legislation in force.

\section{Taxpayer Compliance in Paying Arrears}

To find out the level of taxpayer compliance in paying arrears, as one obligation of taxation, it was known that the actual score has 696 from the ideal score of 1000 and the average value obtained amounted to 3.48. The value was on the criteria of "good". This suggests that taxpayers were already obedient in carrying out the obligations of taxation especially in readiness to pay the arrears following sanctions specified if any fines. In General, this rarely happens because the taxpayer had been carrying out all the obligations in accordance with the tax regulation.

In strengthening the research analysis, the hypothesis proposed and tested by using Path Analysis to see were there direct and indirect effects between variables both partially and simultaneously. The model structure together with their path coefficients could be seen as follows:

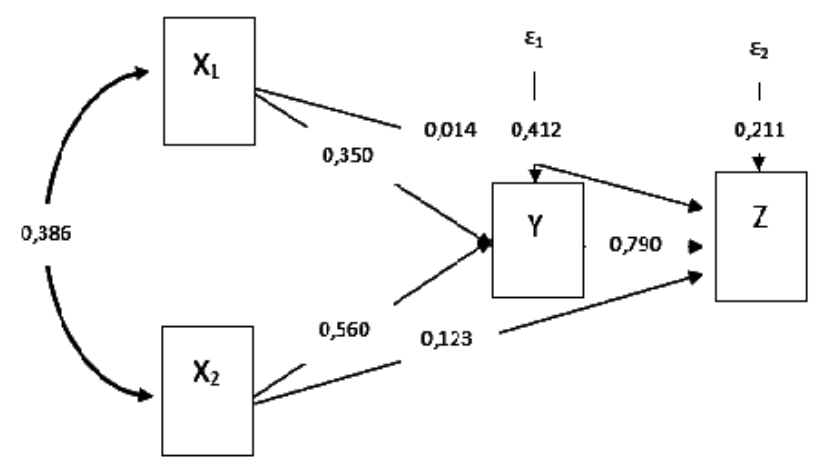

Figure 1.

The Whole Model Structure

This figure showed that socialization through mass media and through face-to-face media significantly affected the tax payers' comprehension about tax regulation both directly and indirectly. This was showed by the correlation of 58.74. Through face to face media had been stronger effect on tax payers' comprehension (38.93 percent) compared to through mass media (19.82 percent). This was showed by Table 1 .

Table 1. The Effects of Variable $X_{1}$ and $X_{2}$ on $Y$

\begin{tabular}{ccccc}
\hline \multirow{2}{*}{ Variable } & \multirow{2}{*}{$\begin{array}{c}\text { Direct } \\
\text { Effects }\end{array}$} & \multicolumn{2}{c}{$\begin{array}{c}\text { Indirect Effects } \\
\text { through }\end{array}$} & \multirow{2}{*}{$\begin{array}{c}\text { Total } \\
\text { Effects }\end{array}$} \\
\cline { 3 - 4 } & & $\mathbf{X 1}$ & $\mathbf{X 2}$ & \\
\hline $\mathbf{X 1}$ & $12,25 \%$ & & $7,57 \%$ & $19,82 \%$
\end{tabular}


HETTI HERAWATI, RONI TABRONI, \& SENNY LUSIANA/ The Effectiveness of The Tax Regulation Socialization Strategies on Tax Payers' Comprehension and Compliance In Implementing Their Tax...

$$
\begin{array}{rrr}
\mathbf{X} 2 \quad 31,36 \% \quad 7,57 \% & 38,93 \% \\
\text { The Effects of variable } \mathbf{X}_{1} \text { and } \mathbf{X}_{2} \text { on } \mathbf{Y} & 58,74 \% \\
\text { The effects of other variables } \mathbf{e}_{1} \text { on } \mathbf{Y} & 41,26 \% \\
\text { Total } & 100,00 \% \\
\hline
\end{array}
$$

Simultaneously, both socialization through media variable and tax payers' comprehension about tax regulation variable affected significantly the tax payers' compliance as strong as 78.84 percent. The tax payers' comprehension had been a stronger effect directly on their tax compliance by 69.69

\begin{tabular}{|c|c|c|c|c|c|}
\hline \multirow[t]{2}{*}{ Variables } & \multirow{2}{*}{$\begin{array}{l}\text { Direct } \\
\text { Effects }\end{array}$} & \multicolumn{3}{|c|}{$\begin{array}{l}\text { Indirect Effects } \\
\text { through }\end{array}$} & \multirow{2}{*}{$\begin{array}{l}\text { Total } \\
\text { Effects }\end{array}$} \\
\hline & & $\mathrm{X} 1$ & $\mathrm{X} 2$ & $\mathbf{Y}$ & \\
\hline $\mathrm{X} 1$ & $0,02 \%$ & & $0,07 \%$ & $0,63 \%$ & $0,71 \%$ \\
\hline X2 & $1,51 \%$ & $0,07 \%$ & & $6,76 \%$ & $8,34 \%$ \\
\hline $\mathbf{Y}$ & $62,41 \%$ & $0,63 \%$ & $6,76 \%$ & & $69,79 \%$ \\
\hline \multicolumn{5}{|c|}{ The effects of variable $X_{1}, X_{2}$, and $Y$ on $Z$} & $78,84 \%$ \\
\hline \multicolumn{5}{|c|}{ The effects of other variables $e_{2}$ on $Z$} & $21,16 \%$ \\
\hline & & & & Total & $100,00 \%$ \\
\hline
\end{tabular}
percent compared to the effect of socialization through media variable on tax compliance variable by rest of it 8.34 percent. This was shown in Table 2.

Table 2. The Effects of Variable $X_{1}, X_{2}$ and $Y$ on $Z$

This table showed that tax payers' comprehension about tax regulation affected their compliance on tax more significantly. This concluded that the hypothesis stated that socialization strategies and tax payers' comprehension variables affected the tax payers' compliance on tax regulation variables effectively and significantly was "accepted".

\section{CONCLUSION}

This research resulted a positive information from the beginning of socialization process to taxpayer compliance aspects. This information becomes important when the Government has a good rule related to taxation, it must be socialized with planned to the public as taxpayers. Socializing done consists of face-to-face to use mass media. The second briefing could not be separated, since it has different functions. What is done by the tax office in West Java, by conducting face-to-face dissemination and using mass media, it can convey to the taxpayer's tax rules.

If the process of socialization is done properly then the taxpayers will understand about regulation including its obligations. While understanding of taxation was correlated strongly with the obedience of taxpayers in fulfilling their obligations. When taxpayers obey rules, it will be very well correlated with the adherence to pay taxes. The study found a strong correlation between understanding, obedience and compliance.

\section{REFERENCES}

[1] newspaper-Sindo.Com/2017

[2] Sugiyono,2008. Methods of Qualitative and quantitative research, $R \& D$. Jakarta: The Alphabet. The thing. 2

[3] Ibid. P. 8

138 | The International Journal of Business Review (The Jobs Review) Vol.1 | No.2 |2018 
[4] Ibid., p. 37

[5] Anwar Arifin. 1984. Science communication: A Concise Introduction. Jakarta: Eagle Press

[6] Donny Binambuni, "Sosialisasi UN its effects on taxpayer compliance in the village of Talaud Islands Regency Karatung, Nanusa Subdistrict," Journal of Economic Research Journal:

EMBA, management, business and Accounting. Volume 1 number 4 Year 2013.

[7] George Herbert Mead. 1863-1931. Mind, Self and Society: From a Standpoint of a Social Behaviorism. Ed. Charles Morris. Chicago: University of Chicago Press.

[8] Oktaviane Lidya Winerungan, "Sosialisasi tax, service tax and sanctions against fiskus compliance wpop in KPP Manado and Bitung KPP," Journal of Economic Research Journal: EMBA, Business, Management And Accounting. Volume 1 number 3 of the year 2013.

[9] Yulanda Atika and Rika Kharlina, "Analisis tax on socialization of taxpayers in an effort to increase acceptance of taxation on KPP Madya Palembang" J urnal Accounting KPP Madya Palembang. Issue 07 year 2015.

[10] Laswell, mass communication Theory, Rajawali, Jakarta: 200 It 37

[11] Ibid., p. 38

$[12]$ Oktaviane Lidya Winerungan, "Socialization of taxation, the Ministry of taxation and sanctions against fiskus compliance WPOP in KPP Manado and Bitung, KPP" Journal of Economic Research Journal: EMBA,management,business and accounting. Volume 1 number 3 of the year 2013.

[13] F Syahril, Influence The Level Of Understanding Of Taxpayers And The Quality Of Service Level Compliance Against Fiskus Tax Payers Of Personal Income Tax Of The People; Journal of accounting, 2013-ejournal.unp.ac.id j

[14] I Gede Putu Pranadata and Rosidi, "the influence of the understanding of the tax payers, tax, service quality and the implementation of sanctions against the taxpayer's compliance with tax people personal tax services Office on the stone Pratama, J Student Scientific urnal FEB Ub. Volume 2 No. 22015 year.

[15] Narwoko\&Cumbersome. 2007. Sociology introductory text and applied. Jakarta: Kencana.

[16] Farid Syahril, "Influence Of The Level Of Understanding Of Taxpayers And The Quality Of Service Level Compliance Against Fiskus Taxpayers PPh People Personal (Empirical Studies On KPP Pratama Solok), " Accounting Journals. Volume 1 number 2 Year 2013.

[17] Farid Syahril, "Influence Of The Level Of Understanding Of Taxpayers And The Quality Of Service Level Compliance Against Fiskus Taxpayers PPh People Personal (Empirical Studies On KPP Pratama Solok)," Accounting Journals. Volume 1 number 2 Year 2013.

[18]. I Gede Putu Pranadata and Rosidi, "the influence of the understanding of the tax payers, tax, service quality and the implementation of sanctions against the taxpayer's compliance with tax people personal tax services Office on the stone Pratama, J Student Scientific urnal FEB Ub. Volume 2 No. 22015 year.

[19] - I Gede Putu Pranadata and Rosidi, "the influence of the understanding of the tax payers, tax, service quality and the implementation of sanctions against the taxpayer's compliance with tax people personal tax services Office on the stone Pratama, J Student Scientific urnal FEB Ub. Volume 2 No. 22015 year.

[20] Erwin Harinurdin, the Agency's Taxpayer Compliance Behaviour, bureaucracy, business \& Administrative Sciences Journals and organizations, may - August 2009, pp. 96-104 Volume 16, number 2 ISSN 0854-384

[21] Soraya Amalia and Abdul Loveland, "Persepsi employee taxes against the utilization of information technology on the performance of individual (case study on KPP PratamaTegal)," Theses Accounting University Of Diponegoro. The year of 2010.

[22] Banu Witono, "the role of Tax Knowledge On Taxpayer Compliance," Journal of Accounting and Finance of Muhammadiyah University of Surakarta. Volume 7 number 2, September 2008. 